\title{
The Development of Media Activities by Undergraduate Students in Order to Promote Agricultural Tourism Community Enterprise According to the Principles of Social Service Learning and Community-Based Leaning
}

\author{
Kuntida Thamwipat ${ }^{1}$, Pornpapatsorn Princhankol ${ }^{1}$, Sakesun Yampinij ${ }^{1}$ \& Sopon Meejaleurn ${ }^{1}$ \\ ${ }^{1}$ Faculty of Industrial Education and Technology, King Mongkut's University of Technology Thonburi, Bangkok, \\ Thailand \\ Correspondence: Kuntida Thamwipat, Faculty of Industrial Education and Technology, King Mongkut's \\ University of Technology Thonburi, Bangkok, Thailand. E-mail: kuntida.tha@kmutt.ac.th
}

Received: January 11, 2018

Accepted: February 15, 2018

Online Published: April 23, 2018

doi:10.5539/ies.v11n5p38

URL: https://doi.org/10.5539/ies.v11n5p38

\begin{abstract}
This research was aimed to develop media activities by undergraduate students to promote agricultural tourism community enterprise according to the principles of social service learning and community-based learning, 2) to evaluate the quality of such media activities, 3) to measure the income of the community after the development of media activities, and 4) to evaluate the satisfaction and the learning achievements of the sampling group. This research was conducted in the second semester of the academic year 2016. There were 5 important phases as in 1) Survey on the concepts and the community's demands, 2) Development of media activities according to ADDIE Model, 3) Evaluation of the quality by 9 experts and the results showed that the contents were of good quality ( $\bar{x}$ $=4.33, \mathrm{SD}=0.63)$ and that the presentation was of good quality $(x=4.48, \mathrm{SD}=0.54), 4)$ Measurement of the income of 34 persons in the community and it showed an average income of 6000 to $12000 \mathrm{Baht}$, or $15 \%$ increase, and the satisfaction of the local shops was at the highest level $(\bar{x}=4.66, \mathrm{SD}=0.54)$, and 5) Evaluation of the satisfaction and the learning achievements of 79 undergraduate students showed that the students expressed the highest level of satisfaction $(x=4.70, \mathrm{SD}=0.26)$. After Action Review (AAR) showed that the learning achievements were good because students gained practical knowledge and used their experience in every step of their activities.
\end{abstract}

Keywords: development of media activities, agricultural tourism community enterprise, social service learning, community-based learning

\section{Introduction}

Agricultural tourism is a type of tourism which brings together the way of life and the traditions of farmers and agriculturists so the tourists can engage with the natural resources through the system of management. In that case, the community needs to collaborate in the activities. Thailand is one country in the ASEAN region with high potentials in this sector. Thailand also has Community Enterprise according to the Act of Community Enterprise B.E.2548 with the aim to promote local wisdom and knowledge, to increase income and to enhance collaboration through agricultural tourism. The state is responsible for the contribution of practical knowledge and the effective management to all community enterprises (Silapa-acha et al., 2015).

In addition to tourism, many people enjoy doing activities in local areas. The panel of experts at Thailand Health Promotion Foundation (THPF) says that during the past 2-3 years Thai people were more aware of their health and activities to promote their well-being in every kind of sports, especially running and cycling. The number of cyclists has increased over $100 \%$ because of the campaign to raise awareness regarding the health and to change the attitudes of working people towards exercise so that they engage in more activities. Further, THPF collaborated with the Order of Cyclists, cycling clubs for health in Thailand and various assemblies to encourage the cabinet to approve of the use of cyclists and assign organizations to make it happen in a concrete manner (Tianmek, 2015).

King Mongkut's University of Technology Thonburi (KMUTT) is a Thai environment-friendly university. It ranks $8^{\text {th }}$ in Thailand and $78^{\text {th }}$ in the world according to "UI Green Metric World University Ranking 2015". Cycles are used instead of carts and the university promotes itself as "Walk \& Bike Society" with the center of Energy, 
Environment, Safety and Health (EESH) as a force behind the campaign. The university is also aware of the social relevance and therefore encourages both faculty members and students to collaborate with local communities and societies in a continuous manner (Center of Energy, Environment, Safety and Health, 2017).

Naksut (2017), the President of Agricultural Tourism Community Enterprise at Wat Buddhabucha said that Bangkok Metropolitan Administration created cycling routes around the community near Bangmod canal and there were many advertisements in radio. However, the campaign was not so popular. Therefore, Naksut contacted the Department of Educational Communications and Technology, Faculty of Industrial Education, KMUTT to promote activities regarding the Agricultural Tourism Community Enterprise in Moo 3 community in Bangmod area.

The undergraduate students at the Department of Educational Communications and Technology, Faculty of Industrial Education, KMUTT recognized the strengths of the community in Moo 3, Bangmod because it was like a field and there was a canal connected to the main river Chaophraya River. There were religious buildings such as wats, mosques and shrines. Although there were signs of modernity in the area, there were still farms and orchards for coconuts, lemons and oranges. In the past, the community suffered from flooding but they still continued growing their fruits in this area. In 2016, the private sector asked the community farmers to sell their local produce and after that time the community has become one of the community enterprises for agricultural tourism. However, the place was not well known in a wider context because it was just in the early stage for cycling routes, the model orchard and the community market.

To make agricultural tourism successful, Nuangchalerm (2015) proposes that the principles social service learning is a good choice. There are 3 steps called PAR. The first step is P-Preparation or a study of the situations and the demands of the community in order to plan and prepare the suitable media activities. The second step is A-Action or a collaboration made by students in order to complete the plan. The third step is R-Reflection or the consideration of the outcome in order to make conclusions and presentations so that the community is aware of the outcome. Based on these steps, the students and the instructors can give advice and further suggestions to the community. This research was part of the academic course called ETM358 Marketing Communications. In this course, the principles social service learning was adopted so that the students could engage in the media activities. The course was for third-year students and this time was the fifth year for this course. All previous communities which participated in the research were located within 10 kilometers from the university. So, the university was quite well received by the local people (Yampinij, 2016). After the completion of the media activities, the learning achievements were evaluated through After Action Review (AAR).

One benefit of this research was that the researchers helped support the Agricultural Tourism Community Enterprise in the local area, in this context, the Community Moo 3, Bangmod. The researchers and the students applied the bodies of knowledge from the course ETM 358 Marketing Communications to launch the campaign "Bike, See, Shop and Taste" to contribute to the community according to the principles of social service learning and community-based learning.

\section{Research purposes}

The purposes of this research were as follows:

1) To develop media activities as initiated by undergraduate students to promote agricultural tourism community enterprise according to the principles of social service learning and community-based learning

2) To evaluate the quality of the media activities as done by undergraduate students to promote agricultural tourism community enterprise according to the principles of social service learning and community-based learning

3) To measure the income of the community after the development of media activities to promote agricultural tourism community enterprise according to the principles of social service learning and community-based learning

4) To evaluate the satisfaction and the learning achievements of the sampling group regarding the social service learning and community-based learning.

\section{Research methodology}

There were 5 important phases in this research. All phases covered the second semester of the academic year 2016. 
Table 1. Research phases

\begin{tabular}{|c|c|c|c|c|}
\hline $\begin{array}{l}\text { Phase } 1 \\
\text { Conceptual survey and } \\
\text { community demands }\end{array}$ & $\begin{array}{l}\text { Phase } 2 \\
\text { Development of media } \\
\text { activities }\end{array}$ & $\begin{array}{l}\text { Phase } 3 \\
\text { Quality evaluation of } \\
\text { media activities }\end{array}$ & $\begin{array}{l}\text { Phase } 4 \\
\text { Income measurement }\end{array}$ & $\begin{array}{l}\text { Phase } 5 \\
\text { Satisfaction and } \\
\text { learning achievements }\end{array}$ \\
\hline $\begin{array}{l}\text { 1. Related ideas and concepts } \\
\text { were gathered. } \\
\text { 2. Conceptualization } \\
\text { 2.1 ADDIE Model was } \\
\text { adopted. It consists of } 5 \text { steps } \\
\text { as in Analysis, Design, } \\
\text { Development, } \\
\text { Implementation } \\
\text { Evaluation. } \\
\text { 2.2 Likert's 5-rating scale } \\
\text { was used to evaluate the } \\
\text { concepts. } \\
\text { 2.3 The } 9 \text { principles of social } \\
\text { service learning as in } \\
\text { - Establishing a model } \\
\text { company } \\
\text { - Extracting lessons learned } \\
\text { from seniors } \\
\text { - Identifying problems in the } \\
\text { community } \\
\text { - Stimulating learning } \\
\text { - Measuring, evaluating and } \\
\text { presenting the results } \\
\text { - Submitting the report to the } \\
\text { contest } \\
\text { - Writing a research report } \\
\text { - What the students learned } \\
\text { and the community gained } \\
\text { - The data/findings were } \\
\text { published } \\
\text { 3. Asking the community for } \\
\text { their demands }\end{array}$ & $\begin{array}{l}\text { 1. Creating media and } \\
\text { training } 30 \text { young guides } \\
\text { for the community } \\
\text { 2. Sharing and discussing } \\
\text { the data with the } \\
\text { community } \\
\text { 3. Announcing the first } \\
\text { cycling event } \\
\text { 4. Organizing the first } \\
\text { cycling event } \\
\text { 5. Creating media activities } \\
\text { to promote the agricultural } \\
\text { tourism } \\
\text { enterprise } \\
\text { 6. Creating a learning area } \\
\text { 7. Advertising (viral video, } \\
\text { poster, fan page, facebook } \\
\text { page) } \\
\text { 8. Organizing the second } \\
\text { cycling event } \\
\text { 9. Discussing the third } \\
\text { cycling event } \\
\text { 10. Announcing the third } \\
\text { cycling event } \\
\text { 11. Organizing the third } \\
\text { cycling event } \\
\text { 12. Project meeting and } \\
\text { closure }\end{array}$ & $\begin{array}{l}\text { The panel of } 9 \text { experts } \\
\text { evaluated the media } \\
\text { activities in these } \\
\text { aspects: } \\
\text { - contents } \\
\text { - media presentation } \\
\text { - measurement and } \\
\text { evaluation }\end{array}$ & $\begin{array}{l}\text { Measuring the income } \\
\text { of } 34 \text { persons in the } \\
\text { community } \\
\text { (Moo 3, Bangmod area) } \\
\text { regarding the } \\
\text { agricultural tourism } \\
\text { community enterprise }\end{array}$ & $\begin{array}{l}\text { 1. Asking } 79 \\
\text { undergraduate students } \\
\text { from the course } \\
\text { ETM358 Marketing } \\
\text { Communications to } \\
\text { evaluate their } \\
\text { satisfaction } \\
\text { 2. Measuring their } \\
\text { learning achievements }\end{array}$ \\
\hline
\end{tabular}

\section{Results}

The results from this research could be presented in 4 sections according to the research purposes.

\subsection{Media Activities to Promote Agricultural Tourism Community Enterprise}

The researchers and the undergraduate students in this research developed media activities according to the ADDIE Model as shown in the following figures: 


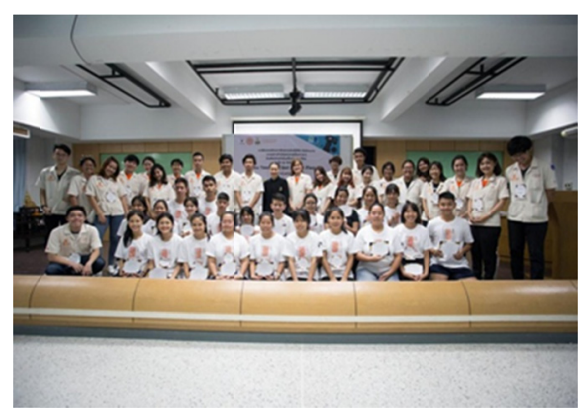

Figure 1. Training young guides for the local community

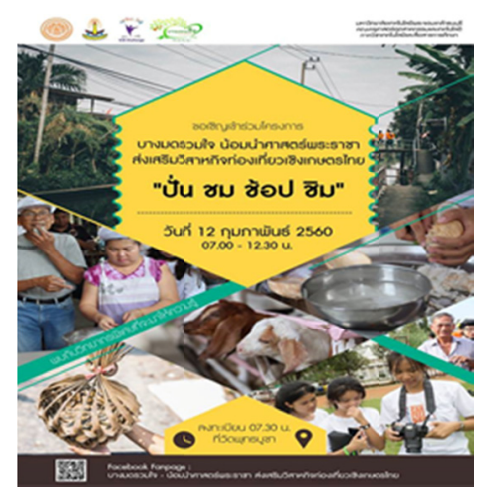

Figure 2. Advertisement/Brochure

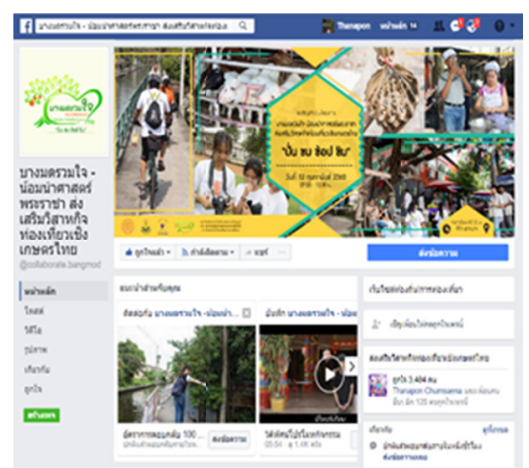

Figure 3. Facebook page for the project

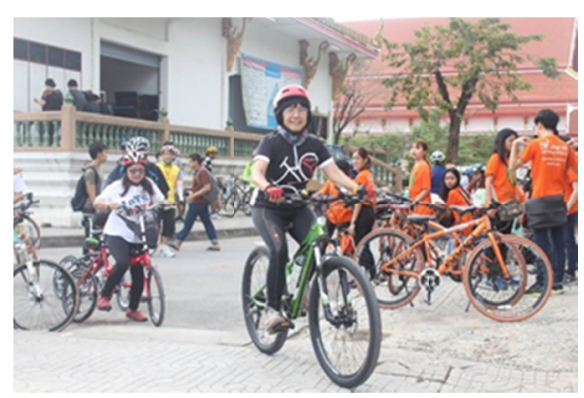

Figure 4. Cycling event 


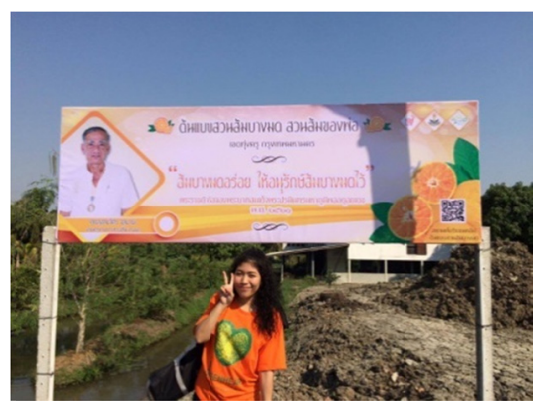

Figure 5. Banner for farm tourism

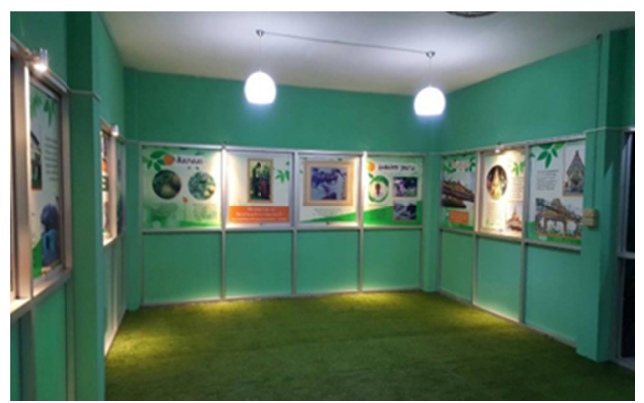

Figure 6. Learning space for the community

\subsection{Quality of the Media and the Activities to Promote Agricultural Tourism Community Enterprise}

The results from the quality evaluation of the media activities developed to promote agricultural tourism community enterprise were shown in Table 2.

Table 2. Quality of media activities

\begin{tabular}{llll}
\hline Aspect & $\bar{x}$ & S.D. & Meaning \\
& & & \\
\hline Contents & 4.33 & 0.63 & Good \\
Media presentation & 4.48 & 0.54 & Good \\
\hline
\end{tabular}

According to Table 2, the quality of the media activities developed to promote agricultural tourism community enterprise was evaluated by the panel of experts. It was of good quality in terms of contents $(\bar{x}=4.33, \mathrm{SD}=0.63)$ and of good quality in terms of media presentation $(x=4.48, \mathrm{SD}=0.54)$. The results confirmed the research hypothesis.

\subsection{Income Evaluation}

The income of the local community after the development of media activities to promote agricultural tourism community enterprise was evaluated and the results are shown in Table 3.

Table 3. Income evaluation of the community

\begin{tabular}{cccc}
\hline $\begin{array}{c}\text { Average income per month } \\
\text { (Baht) }\end{array}$ & $\begin{array}{c}\text { Increase of income after the activities (including } 3 \text { cycling } \\
\text { events) }\end{array}$ & $\begin{array}{c}\text { Satisfaction of the local } \\
\text { shops }\end{array}$ & Meaning \\
\hline $6,000-12,000$ Baht & $15 \%$ & $\bar{x}=4.66, \mathrm{SD}=0.54$ & The \\
Highest
\end{tabular}

According to Table 3, the evaluation of the income earned by 34 persons in the community Moo 3, Bangmod from their local shops as in fruit shops, coffee shops, restaurants, desserts shops, salons, herbal shops, bakeries, 
fishmongers, belt sellers and the like shows that the average income per month was between 6,000 and 12,000 Baht before the media activities. After the 3 cycling events, the income increased by $15 \%$. The satisfaction of the local shops was at the highest level ( $\bar{x}=4.66, \mathrm{SD}=0.54)$, confirming the research hypothesis.

\subsection{Satisfaction of the Sampling Group towards the Social Service Learning and Community-Based Learning}

The satisfaction of the sampling group, i.e., the undergraduate students, towards the social service learning and community-based learning is shown in Table 4.

Table 4. Satisfaction of the sampling group

\begin{tabular}{llll}
\hline \multirow{2}{*}{ Aspect } & $\bar{x}$ & S.D. & Meaning \\
& & & \\
\hline Satisfaction & 4.70 & 0.26 & The Highest \\
\hline
\end{tabular}

The results from the evaluation of the satisfaction of the sampling group (undergraduate students) towards the social service learning and community-based learning which consisted of 9 steps as proposed by the researchers showed that the students expressed the highest level of satisfaction, confirming the research hypothesis.

After the project, the After Action Review shows that the learning achievements of students were at a good level. The majority of the students recognized that the development of media activities allowed them to use their knowledge and experience in a practical use in every stage. It also created a good relationship between the university and the neighboring community.

\section{Discussion}

\subsection{Development of Media Activities}

The researchers and the undergraduate students followed the ADDIE Model (Anukulwech, 2017) in this project which consists of Analysis, Design, Development, Implementation and Evaluation. The media activities were successful. The research phases in this project were similar to the ones used in the research project entitled "Developing a Lesson Based on the 'Service-Learning' Principle through the Project to Create a Community Calendar to Promote 12 Values" (Thamwipat, Princhankol, \& Kaewket, 2017) and the research project entitled "Chula Kite Local Wisdom" of Suan Thonburirom Community through Social Service Learning Approach by Students from Faculty of Industrial Education and Technology, KMUTT" (Mateeboonviriyakul, Princhankol, \& Thamwipat, 2016) which adopted the ADDIE Model as a way to promote social service learning.

\subsection{Quality of Media Activities}

The quality of the media activities to promote agricultural tourism community enterprise was at a good level for both contents $(\bar{x}=4.33, \mathrm{SD}=0.63)$ and media presentation $(\bar{x}=4.48, \mathrm{SD}=0.54)$. The findings confirmed the research hypothesis because the researchers consulted the community members continuously and also sought advice from the panel of experts regarding the media activities. Moreover, there were a fan page and a Facebook page for others to give comments on the social media. Therefore, the quality of media activities was at a good level. This aspect is similar to the one suggested by Laothiang (2017) in that the online social network has become a social tool for the social network. Both senders and receivers are collaborative in their contents in a creative manner. The use of social network with the education could result in both increased interest and collaboration between the instructors and the students.

\subsection{Income Evaluation after the Development of Media Activities}

According to the data regarding the income of 34 persons in the community Moo 3, Bangmod area, it was found that the average income per month was between 6,000 and 12,000 Baht before the media activities. After the 3 cycling events and the activities, the income increased by $15 \%$. The satisfaction of the local shops towards the project was at the highest level ( $\bar{x}=4.66, \mathrm{SD}=0.54)$, confirming the research hypothesis. This is similar to the research entitled "Local Brand Building and Brand Communication Strategy and Brand Image Perception of Entrepreneurs: Chiangmai Brand Case Study" done by Limpiti (2013) who found that the use of social media, websites, billboards, posters and activities could increase the sales of the local entrepreneurs who used Chiangmai Brand, resulting in both increased income and increased quality image. 


\subsection{Satisfaction and Learning Achievements of the Sampling Group towards the Social Service Learning and Community-Based Learning}

There were 9 principles of social service learning. The undergraduate students expressed the highest level of satisfaction towards this approach $(\bar{x}=4.70, \mathrm{SD}=0.26)$. Moreover, the learning achievements confirmed the research hypothesis. The researchers followed the model of social service learning as suggested by Thamwipat and Princhankol (2017). The 9 principles could be explained as follows:

1) Establishing a model company, in this case, ECT Agency:

- All students were assigned works according to willingness and talents

- All students attended the meeting to choose the president and the committee members

- Meetings were held every week in order to reflect on the progress and to consult the supervisors

2) Extracting lessons learned from seniors in order to find out the best practices and how to improve the previous ones

3) Identifying problems in the community by asking the community members through learning and sharing

4) Stimulating learning in classrooms through social service learning which consists of 4 steps as in Creating, Stimulating, Giving and Contributing

Table 5. Social service learning steps

\begin{tabular}{|c|c|c|c|}
\hline $\begin{array}{c}\text { Step } 1 \\
\text { Creating }\end{array}$ & $\begin{array}{c}\text { Step } 2 \\
\text { Stimulating } \\
\end{array}$ & $\begin{array}{l}\text { Step } 3 \\
\text { Giving }\end{array}$ & $\begin{array}{c}\text { Step } 4 \\
\text { Contributing } \\
\end{array}$ \\
\hline $\begin{array}{l}\text { Creating a democratic } \\
\text { environment in the class by } \\
\text { assigning works to individuals } \\
\text { based on good governance, } \\
\text { transparency, and self-sufficiency } \\
\text { philosophy }\end{array}$ & $\begin{array}{l}\text { Stimulating students to see } \\
\text { problems or what the } \\
\text { community demands so that } \\
\text { they can help the community } \\
\text { achieve a better quality of } \\
\text { life }\end{array}$ & $\begin{array}{l}\text { Giving freedom to students to express } \\
\text { their viewpoints and to take } \\
\text { responsibilities regarding the design } \\
\text { of media activities appropriate to the } \\
\text { context. The instructors become a } \\
\text { coach. }\end{array}$ & $\begin{array}{l}\text { Contributing the media } \\
\text { activities which are designed } \\
\text { by students to others. Both the } \\
\text { instructors and other learners } \\
\text { can learn from these activities. }\end{array}$ \\
\hline
\end{tabular}

5) Measuring, evaluating and presenting the results through the Plan, Do, Check, Act principle.

6) Submitting the report to the contest so that the students learned how to present their work and to gather all data

7) Writing a research report to present the findings in a national or international conference so that the report became available and accessible to others

8) The benefit was mutural. The students learned and the community gained because they worked under the principle of Win-Win situation.

9) The data/findings were published to other communities so that other people would pay more attention to the project, resulting in an increased interest in agricultural tourism community enterprise and the benefits to the local communities. The Faculty has already done similar projects every year for the past 5 years.

\section{Suggestions}

\subsection{Suggestions from the Research Results}

1) The agricultural tourism community enterprise should be encouraged in a sustainable manner. Therefore, the researchers have asked the following organizations to continue their support:

- Culture, Sports and Tourism Department, Bangkok Metropolitan Authority (BMA)

- Community development and welfare service, Toong-kru District

- Student society to support young guides in the local community in collaboration with Wat Buddhabucha to promote agricultural tourism community enterprise

- Cycling society to organize activities every Saturday and Sunday (KMUTT Green Society) so that there is at least one or two activities per month in the community.

2) To use the principles of social service learning in any course, the instructors should encourage students to apply their knowledge in the real community so that they learn how to work under a democratic society and that they can use their talent to their full potential. 


\subsection{Suggestions for Further Research}

1) There should be a research study into the development of media activities to promote agricultural tourism community enterprise according to the concept of Thailand 4.0 through the principles of social service learning.

2) There should be a study into the factors which affect the social service learning of undergraduate students at the Faculty of Industrial Education in Thailand.

\section{References}

Anukulwech, A. (2017). ADDIE Model. Retrieved from http://lms.thaicyberu.go.th/

Center of Energy, Environment, Safety and Health. (2017). Walk and Bike Society. Retrieved from http://www.eesh.kmutt.ac.th/doc/eesh_index_t.asp

Laothiang, C. (2017). Social media and education. Retrieved from http://smforedu.blogspot.com/2014/02/blog-post.html

Limpiti, S. (2013). Local Brand Building and Brand Communication Strategy and Brand Image Perception of Enterpreneurs: Chiangmai Brand Case Study (Unpublished master's thesis). Chiangmai University, Chiangmai, Thailand.

Mateeboonviriyakul, K., Princhankol, P., \& Thamwipat, K. (2016, November). The Development of Learning Resources "Chula Kite Local Wisdom" of Suan Thonburirom Community through Social Service Learning Approach by Students from Faculty of Industrial Education and Technology, KMUTT. Paper presented at the $42^{\text {nd }}$ Congress on Science and Technology (STT42), Bangkok, Thailand.

Naksut, S. (2017, January 8). Agricultural Tourism Community Enterprise at Moo 3, Bangmod [Personal communication].

Nuangchalerm, P. (2015). Social service learning. Rajabhat Kalasin Academic Journal. 2(1), 9-18.

Silapa-acha, W. et al. (2015). The context of Thai Agrotourism Community Enterprise. Retrieved from $\mathrm{http}: / / \mathrm{www}$. sms-stou.org/archives/567?lang=th

Thamwipat, K., \& Princhankol, P. (2017, October 2). Innovation for Democracy through Social Service Learning in a Community [Personal communication].

Thamwipat, K., Princhankol, P., \& Kaewket, N. (2017, April). Developing a Lesson Based on the 'Service-Learning' Principle through the Project to Create a Community Calendar to Promote 12 Values. Paper presented at the $3^{\text {rd }}$ rd International Conference on Education and Distance Learning 2017, Colombo, Srilanka.

Tianmek, N. (2015). Thai people, cycle now. Retrieved from http://www.thaihealth.or.th/Content/29147

Yampinij, S. (2016, December 15). Social service learning at KMUTT [Personal communication].

\section{Copyrights}

Copyright for this article is retained by the author(s), with first publication rights granted to the journal.

This is an open-access article distributed under the terms and conditions of the Creative Commons Attribution license (http://creativecommons.org/licenses/by/4.0/). 